\title{
CHANGES IN LANDSCAPE STRUCTURE IN A RURAL AREA OF BOSO PENINSULA, CENTRAL JAPAN
}

\author{
Michiro FUJIHARA ${ }^{1}$, KeITAROU HARA ${ }^{2}$
}

${ }^{1}$ Graduate School of Landscape Design and Management, University of Hyogo /Awaji, Landscape Planning and Horticulture Academy, 654-2 Nojimatokiwa, Awaji-city, Hyogo 656-1726, Japan

${ }^{2}$ Tokyo University of Information Sciences, 1200-2 Yatoh-cho, Wakaba-ku, Chiba 2608501, Japan, Corresponding author, Phone and Fax: 81-799 82 3172; e-mail: fujihara@awaji.ac.jp

Received: $5^{\text {th }}$ September 2010, Accepted: $26^{\text {th }}$ December 2011

\begin{abstract}
Landscape structure and land use history were clarified based on the old maps in the Boso Peninsula, central Japan. Landscape map dated around the 1880s was created through modification of old maps and landscape map from the 1980s was made based on actual vegetation maps. Natural vegetation of this area was evergreen broad leaved forest. Around the 1880s, evergreen coniferous forest composed of Pinus densiflora and deciduous broad leaved forest composed of $Q$. serrata were dominant together with many patches of grassland found on the Boso Peninsula. Prior to the 1960s, grassland products were used for several traditional purposes such as fertilizer or roofing material; shrubs were used for fuel and litter for compost. After the 1960s, these areas were abandoned due to the lack of need for traditional use. Some abandoned vegetated areas changed into late succession stages, others were changed to artificial land use. Areas of forest vegetation in the 1980s increased comparing to the 1880s. The species composition of forests on former forested areas reflected the intensity of disturbance by residential people.
\end{abstract}

\section{INTRODUCTION}

Human modification of forests is a major component of the global environmental change. Even areas that remain predominantly forested may be changed considerably by human alteration of historical disturbance regimes (Wimberly and Ohmann 2004). Human activities are major forces in shaping landscape, creating a mosaic of natural and human-managed patches that vary in size, shape, and arrangement. The scientific and resource management community still do not fully understand the cumulative impact of human pressures at the landscape level. The links between human activities, landscape pattern, and ecological process need to be clarified. It is known that changes in area, shape and connectivity of patches cause changes in species richness, distribution and persistence of populations. It may be stated that understanding of ecological principles of changing pattern forms the landscape pattern. In order to clarify the process of changing landscapes in human-made landscape, ecological and socio-economic 
monitoring is important. We need monitoring program for land use change, species shifts and developing detailed scenarios.

Shirai (1992) documented that three fundamental land use types, such as residential, cultivated and woodland, were found within a relatively small area, so the residents could obtain essential materials from the local vicinity in the northern part of the Boso Peninsula until the 1960s. Most energy and materials were derived from woodlands around the residential area. Farmland landscape consisted of these land use types. Grassland was also important material source. In Japan, fertilizer and fuels changed drastically from plant materials to chemical ones and petroleum after the 1960s. Arizono (1994) described that essential energy source changed from fuel wood obtained from vicinity to petroleum obtained from far away. Material circulation also seemed to have deteriorated. Fujihara and Shirai (2001) documented landscape change in five different topographical areas and these changes were affected by farm system as socio-economic monitoring. Landscape structure is considered to be influenced by these socio-economic changes. Helliwell (1976) pointed out that the management history of a forest may be important in determining its floristic composition. Kadmon and Pulliam (1993) reported that the influence of isolation on species richness varied between past forest management types. Iida \& Nakashizuka (1995) documented forest fragmentation and its effect on species diversity in sub-urban coppice forests. On the other hand, landscape analysis with timeseries maps and aerial photographs has been carried out and has helped our recognition of landscape change (Cousins 2001 and Kienast 1993). Traditional landscapes in the past provide valuable knowledge for sustainable management of future landscapes (Antrop 2005). However, little work has been done in quantifying the spatial pattern of historical vegetation change since the Meiji era in Japan. We quantified general aerial maps of vegetation in forest cover through time and related these changes to the land use or ecosystem process driving change. In this paper, we compare the landscape structure in terms of kinds, number and size of patches in landscape. Secondary we revealed species shifts due to the history of land use.

\section{STUDY AREAS AND SITES}

Study area (Amaariki) is located at central part of the Boso Peninsula, eastern Japan (Fig. 1). The Boso Peninsula is located about $50 \mathrm{~km}$ southeast apart from Tokyo and is of the length of $100 \mathrm{~km}$. This area is divided into two parts by many aspects. Geographically, the northern part consists of lowland, whereas mountain area dominates in the southern part. Natural evergreen broad-leaved forests dominated in the southern part, on the other hand the northern part used to be dominated by secondary deciduous forests. Human impacts are more severe in the northern part (Fujihara and Shirai 2001). Study area was selected in a rural area located in the middle of the Boso Peninsula. Mean annual temperature and annual precipitation based on a meteorological station near from study site $\left(35^{\circ} 36.1 \mathrm{~N}, 140^{\circ} 06.2 \mathrm{E}\right.$ : Chiba) are $15.8{ }^{\circ} \mathrm{C}$ and $1696 \mathrm{~mm}$ (Japan Meteorological Agency 1995). Potential natural vegetation in this area is evergreen broad-leaved forest. Urban land use, such as residential areas, industrial areas and areas for transport systems, has been expanding north around Tokyo bay (Fujihara and Shirai 2001). Human impacts seem to be moderate in this area, because a large urbanized area has not yet appeared there. Landscape structure was studied in two sites: one is Fukumasu (study site-a) another is Sakuraya (study site-b). Distance between these two sites is about $10 \mathrm{~km}$. 


\section{METHODS}

Landscape maps of the middle part of the Boso Peninsula in the 1880 s were made from "Jnsoku Sokuzu" (land use maps made by Japanese army in Meiji era), and those of the1980s were drawn based on vegetation maps made by Environmental Agency of Japan. The scale of our maps is 1:25,000. Forest, grassland, cultivated land and urban land use were identified in all landscape maps. The area of each landscape element was measured mainly by GIS systems. In the case of the Boso Peninsula, using these vegetation maps, the size and number of each landscape element were measured. Strait line was drawn at $50 \mathrm{~m}$ intervals, and the number of vegetation types at cross point of rectangular lines was counted. The ratio of area of each vegetation type was considered to be identical to the ratio of number of each vegetation type.

In order to clarify the effect of former land use type to species composition, four and five quadrats $(10 \times 10 \mathrm{~m})$ were established in the forest-former grassland and forest, respectively at site-a. Five quadrants $(10 \times 10 \mathrm{~m})$ were established in the forest -former forest, at site-b. Species name, cover-abundance and sociability (Braun-Blanquet 1964, Mueller-Dombois and Ellenberg 1974) of all vascular plants were recorded in each quadrant. The area of farmland and volume of crops of each village was derived from field record "Teisatsuroku". The traditional unit of the crop yield of Japan is "koku" and it means the volume.

\section{RESULTS}

\section{Landscape structure in the 1880s.}

Pine forest and grassland were widely distributed in the 1880s (Fig.1-A). In the western part, grassland predominated, while pine forest predominated in the eastern part. Forests and paddy fields were not very fragmented: each patch of landscape element was large. Table 1 shows the area of each landscape element types at the two study sites in the 1880s. Oak forest (coverage: $39.6 \%$ ) and grassland (33.6 \%) predominated at Fukumasu (site-a). Most oak forests were deciduous. Pine forests $(55.6 \%)$ and paddy fields $(34.7 \%)$ predominated at Sakuraya (site-b). Many evergreen and deciduous oak trees were present in the pine forests. The paddy field area was larger on site-b than on site-a, while field area was larger on site-a than site-b. Residential area was less than $1 \%$ on both study sites.

Table 1: Area of each vegetation type on two study sites in 1880s

\begin{tabular}{llrrrrr}
\hline $\begin{array}{l}\text { Landscape } \\
\text { element type }\end{array}$ & & \multicolumn{2}{c}{ site-a } & & \multicolumn{2}{c}{ site-b } \\
& & $\begin{array}{r}\text { Ratio } \\
(\%)\end{array}$ & $\begin{array}{r}\text { Area } \\
\text { (ha) }\end{array}$ & $\begin{array}{r}\text { Ratio } \\
(\%)\end{array}$ & $\begin{array}{r}\text { Area } \\
\text { (ha) }\end{array}$ \\
\hline Forest & Pine & 5.5 & 22.1 & & 55.6 & 222.5 \\
& Oak & 39.6 & 158.5 & & 1.9 & 7.6 \\
Shrub & & & & 2.1 & 8.6 \\
Grassland & & 33.6 & 134.4 & & \\
Cultivated & Tea & 0.3 & 1.2 & & \\
& Field & 10.1 & 40.5 & 5.2 & 20.7 \\
& Paddy field & 10.2 & 40.9 & 34.7 & 139.0 \\
Open water & & 0.2 & 0.7 & 0.1 & 0.2 \\
Residential & & 0.4 & 1.7 & 0.4 & 1.4 \\
\hline Total & & 100 & 400 & 100 & 400 \\
\hline
\end{tabular}


Fig. 1: Landscape maps of the central part of the Boso Peninsula. A: 1880s. B: 1980s
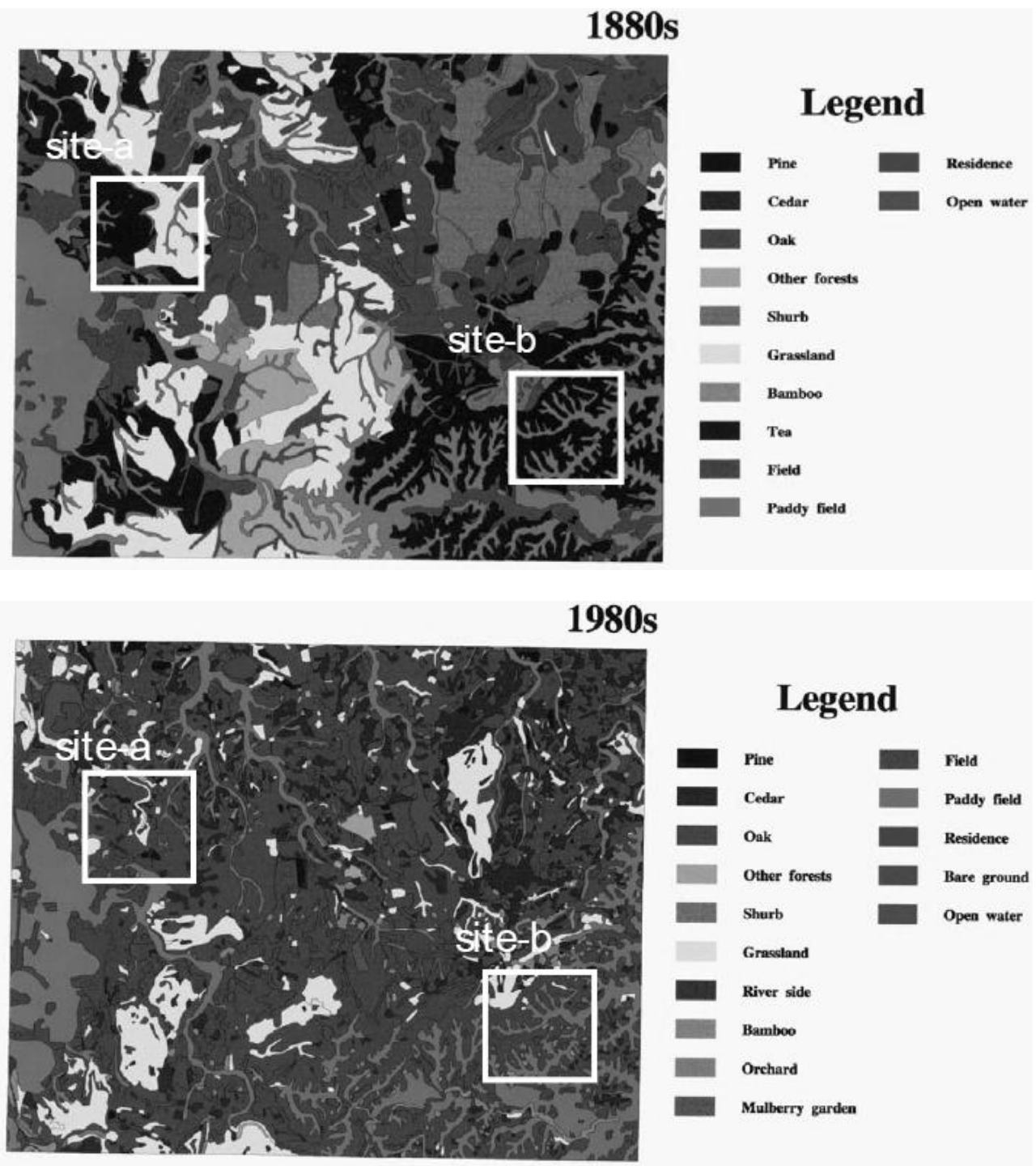

\section{Landscape structure in the 1980s}

One large reservoir (Included in "open water"), several golf courses (included in "grassland") and many residences had been constructed by the 1980s (Fig. 1-B). Japanese cedar plantations were frequently distributed in all areas except for the plain. Each patch of landscape element was fragmented. Deciduous oak forest was widely distributed in the western part, and evergreen oak forest was distributed in the eastern part. Most of large grasslands were golf courses. Table 2 shows the area of each landscape element type on the two study sites in the 1980s. Deciduous oak forest (coverage: $53.2 \%$ ) covered more than half of the study area on site-a. Evergreen oak forest (49.0\%) and paddy fields (34.9\%) 
predominated at site-b. Japanese cedar plantations and bamboo communities appeared on both study sites. Residential area was greater than $2 \%$ at both study sites.

Table 2: Number of patches and area of each vegetation type on two study sites in 1980

\begin{tabular}{llrrrrr}
\hline \multirow{2}{*}{$\begin{array}{l}\text { Landscape } \\
\text { element type }\end{array}$} & & \multicolumn{3}{c}{ site-a } & & \multicolumn{2}{c}{ site-b } \\
\cline { 7 - 7 } \cline { 6 - 7 } & & $\begin{array}{r}\text { Ratio } \\
(\%)\end{array}$ & $\begin{array}{r}\text { Area } \\
\text { (ha) }\end{array}$ & $\begin{array}{r}\text { Ratio } \\
(\%)\end{array}$ & $\begin{array}{r}\text { Area } \\
\text { (ha) }\end{array}$ \\
\hline Forest & Pine & 2.2 & 8.8 & & \\
& Cedar & 9.5 & 38.1 & 3.6 & 14.3 \\
& Evergreen Oak & & & 49.0 & 196.1 \\
& Deciduous Oak & 53.2 & 213.0 & 0.7 & 2.9 \\
& Others & 1.5 & 6.2 & & \\
Bamboo & & 0.7 & 2.6 & 3.1 & 12.4 \\
Grassland & Miscanthus & 1.8 & 7.1 & & \\
& Cultivated meadow & 0.5 & 2.1 & 1.7 & 6.9 \\
& Golf link & & & 0.4 & 1.7 \\
& Uncultivated Field & 2.4 & 9.5 & 2.1 & 8.3 \\
& Uncultivated Paddy field & 2.0 & 8.1 & 0.8 & 3.3 \\
Cultivated & Others & 0.2 & 1.0 & & \\
& Field & 15.4 & 61.6 & 0.4 & 1.7 \\
Open water & Paddy field & 7.9 & 31.7 & 34.9 & 139.4 \\
Residential & & 0.2 & 0.7 & 0.5 & 1.9 \\
\hline Total & & 2.4 & 9.5 & 2.8 & 11.2 \\
\hline
\end{tabular}

\section{Changes in landscape structure}

Table 3 shows the changes in landscape pattern on the two study sites. At site-a, Japanese cedar plantations can be detected on former oak forest $(5.41 \%)$ and grassland $(3.09 \%)$ (Table 3-A). Most grassland changed into oak forest $(21.53 \%)$, and the remaining grassland changed into cultivated fields $(5.12 \%)$, Japanese cedar plantations $(3.09 \%)$ and pine forest $(1.25 \%)$. Several paddy fields $(2.02 \%)$ and cultivated fields $(0.95 \%)$ changed into grassland because of abandonment of cultivation. On site-b, most pine forests changed into evergreen oak forests $(47.89 \%)$, and remaining pine forests changed into bamboo communities (3.09\%), Japanese cedar plantations $(2.32 \%)$ and residences $(1.01 \%)$ (Table 3 -B). Several cultivated fields $(0.54 \%)$ and paddy fields $(0.59 \%)$ changed into grassland because people abandoned cultivation. The size and shape of most paddy fields $(31.17 \%)$ remained the same.

\section{Disturbance regimes}

Table 4 shows the productivity of rice and other crops in each village at the two study sites in the 1880s. Productivity of other crops is high at study site-a. In the 1880s most fuel and fertilizer were plant materials obtained from grasslands and forests. In the $1880 \mathrm{~s}$ grassland were mowed in site-a and the shrub and herb layers under the canopy were cleared on both sites. Grassland was maintained through frequent mowing in warm temperate Japan, because if this kind of disturbance is not maintained, grassland can change to forest. The frequency and level of the disturbances seems to have been greater on site-a than site-b. Most of areas on site-a were covered by low hills, on the other hand, complicated narrow, branching valleys and mountains with ridges were present on site-b. 
Table 3: Transition matrices for study sites: A. Fukumasu(site-a), B. Sakuraya(site-b)

A. Fukumasu(site-a)

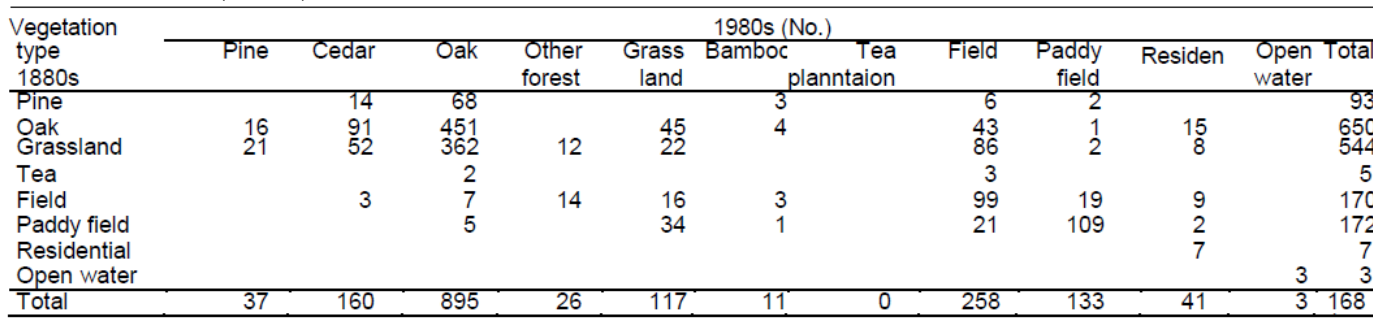

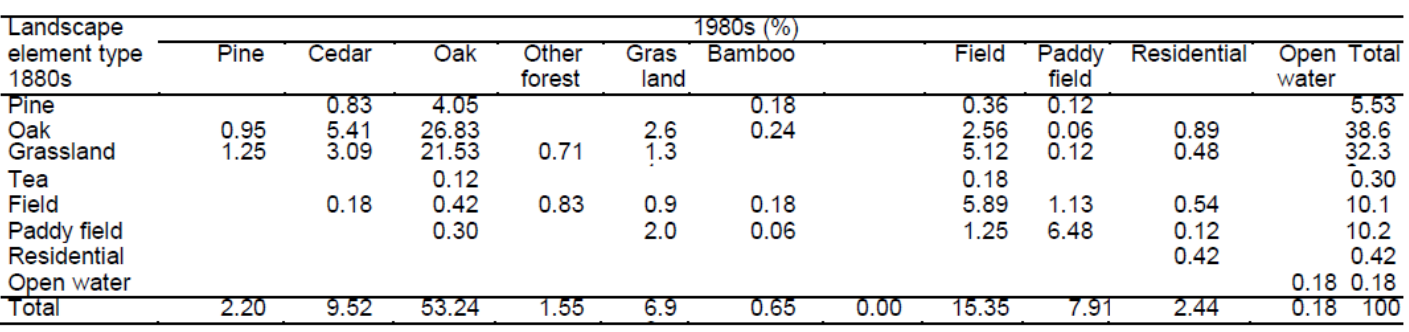

B. Sakuraya(site-b)

\begin{tabular}{|c|c|c|c|c|c|c|c|c|c|c|}
\hline \multirow{2}{*}{$\begin{array}{l}\text { Vegetation } \\
\text { type } \\
1880 \mathrm{~s}\end{array}$} & \multicolumn{10}{|c|}{$1980 \mathrm{~s}$ (No.) } \\
\hline & Cedar & $\begin{array}{c}\text { Evergreen } \\
\text { oak }\end{array}$ & $\begin{array}{c}\text { Deciduous } \\
\text { oak }\end{array}$ & $\begin{array}{l}\text { Grass } \\
\text { land }\end{array}$ & Bamboo & Field & $\begin{array}{l}\text { Paddy } \\
\text { field }\end{array}$ & Residential & $\begin{array}{l}\text { Open } \\
\text { water }\end{array}$ & Total \\
\hline$\overline{\text { Pine }}$ & 39 & 805 & 6 & 6 & 52 & 2 & 8 & 17 & & 935 \\
\hline Evergreen Oak & 6 & & 6 & 20 & & & & & & 32 \\
\hline Other forest & 2 & & & 34 & & & & & & 36 \\
\hline Field & 4 & 9 & & 9 & & 5 & 54 & 1 & 5 & 87 \\
\hline Paddy field & 9 & 10 & & 16 & & & 524 & 24 & 1 & 584 \\
\hline Residential & & & & & & & & 6 & & 6 \\
\hline Open water & & & & & & & & & 1 & 1 \\
\hline Total & 60 & 824 & 12 & 85 & 52 & 7 & 586 & 48 & 7 & 1681 \\
\hline Landscape & & & & 80 s $(\%)$ & & & & & & \\
\hline $\begin{array}{l}\text { element type } \\
1880 \text { s }\end{array}$ & Cedar & $\begin{array}{c}\text { Evergreen } \\
\text { oak }\end{array}$ & $\begin{array}{r}\text { Deciduous } \\
\text { oak }\end{array}$ & $\begin{array}{l}\text { Grass } \\
\text { land }\end{array}$ & Bamboo & Field & $\begin{array}{l}\text { Paddy } \\
\text { field }\end{array}$ & Residential & $\begin{array}{l}\text { al Open } \\
\text { water }\end{array}$ & Total \\
\hline Pine & 2.32 & 47.89 & 0.36 & 0.36 & 3.09 & 0.12 & 0.48 & 1.01 & & 55.62 \\
\hline Evergreen Oak & 0.36 & & 0.36 & 1.19 & & & & & & 1.90 \\
\hline Other forest & 0.12 & & & 2.02 & & & & & & 2.14 \\
\hline Field & 0.24 & 0.54 & & 0.54 & & 0.30 & 3.21 & 0.06 & 0.30 & 5.18 \\
\hline Paddy field & 0.54 & 0.59 & & 0.95 & & & 31.17 & 1.43 & 0.06 & 34.74 \\
\hline Residence & & & & & & & & 0.36 & & 0.36 \\
\hline Open water & & & & & & & & & 0.06 & 0.06 \\
\hline Total & 3.57 & 49.02 & 0.71 & 5.06 & 3.09 & 0.42 & 34.86 & 2.86 & 0.42 & 100 \\
\hline
\end{tabular}

Topography of site-a is considered to be gentle. In the 1980s most land management happened on site-a compared to site-b. In the 1980s most land management was abandoned except for cultivated patches (paddy fields, fields and some of Japanese cedar plantations) on both sites. 
Table 4: Productivity of rice and other crops in each village on the two study sites

Site-a

\begin{tabular}{lccc}
\hline & \multicolumn{3}{c}{ Productivity $\left(\mathrm{m}^{3} / \mathrm{ha}\right)$} \\
\cline { 2 - 4 } Village & Rice & Other crops & Total \\
\hline Shinnbori & 2.23 & 2.91 & 2.40 \\
Fukumasu & 1.99 & 2.79 & 2.28 \\
Takeshi & 2.15 & 2.85 & 2.44 \\
Yamakura & 1.78 & 2.64 & 2.17 \\
Otabe & 3.24 & 2.58 & 2.96 \\
\hline Total & 2.18 & 2.76 & 2.39 \\
\hline
\end{tabular}

Site-b

\begin{tabular}{lcccc}
\hline & \multicolumn{3}{c}{ Productivity $\left(\mathrm{m}^{3} / \mathrm{ha}\right)$} \\
\cline { 2 - 4 } Village & Rice & Other crops & Total \\
\hline Tokumasu & 2.07 & 1.53 & 1.1 & 1.86 \\
Sakuraya & 2.15 & 1.59 & + & 1.95 \\
Nagatomi & 2.08 & 1.52 &. & 1.90 \\
Yamane & 2.43 & 2.03 & .2 .33 \\
Chiyomaru & 1.82 & 1.66 & 1.77 \\
\hline Total & 2.21 & 1.71 & 2.05 \\
\hline
\end{tabular}

\section{Species composition}

Table 5 shows the species composition in 1996 in each quadrant of forests on former grassland and on former forests on site-a and in forests that didn't change use on site- $\mathrm{b}$. At Fukumasu (site-a), Quercus accutissima is present in the quadrants of forests on former grassland (Table 5).

The Castanopsis cuspidata group, such as Castanopsis cuspidata, Ophiopogon japonicus and $O$. japonicus var. umbrosus etc. is present in the quadrants of forests on former forests on both sites. At Sakuraya (site-b), the Quercus glauca group, such as Q. glauca, Heterotropa nipponicum and Ligustrum japonicum etc. is present in the quadrants of forests on former forests (Table 6).

Table 5: Species composition in the quadrants of the two study sites.

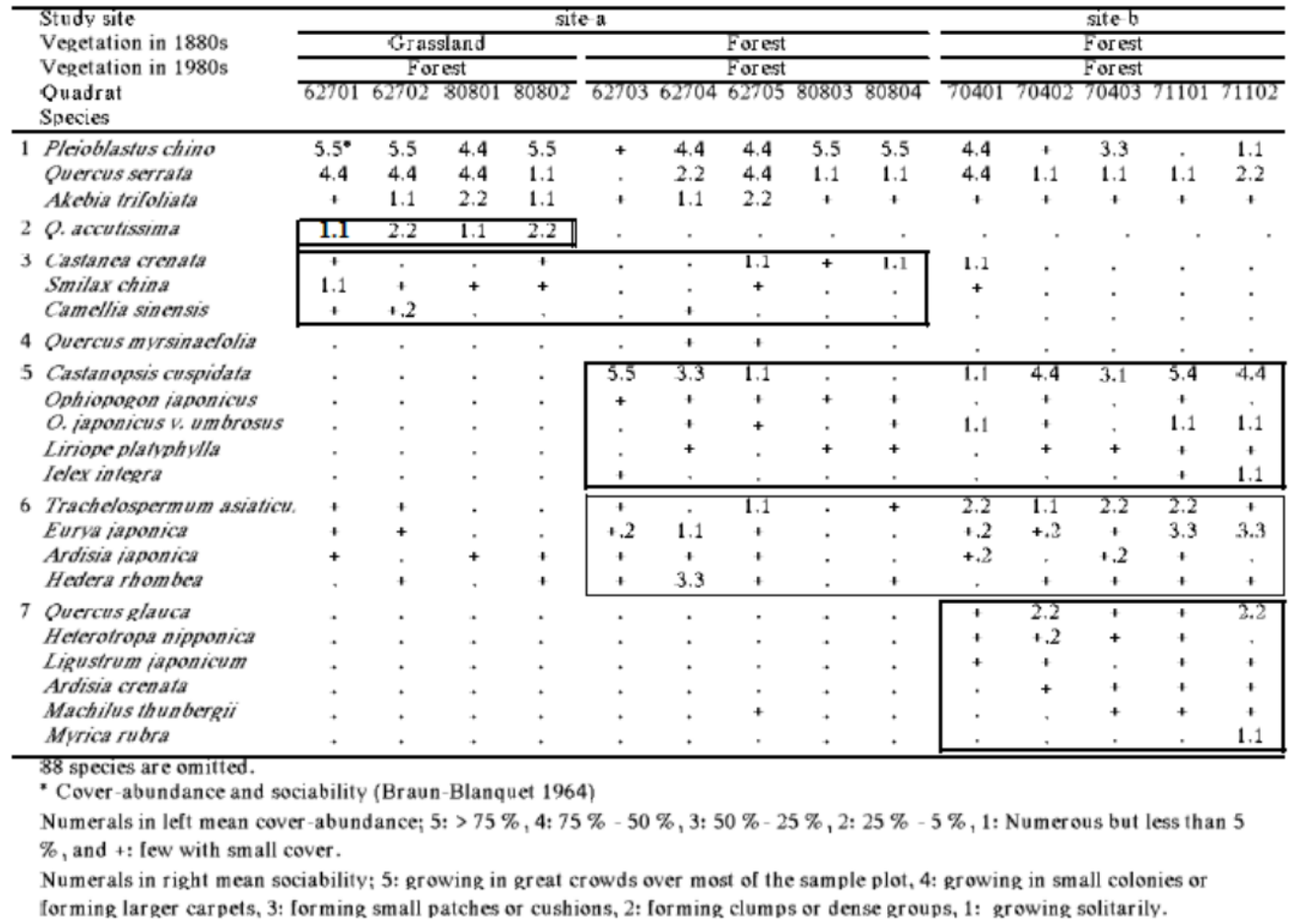


Table 6: Conceptual landscape structures on the two study sites

\begin{tabular}{|c|c|c|}
\hline & site-a & site-b \\
\hline Topography & gentle & steep \\
\hline Disturbance regimes & high & low \\
\hline \multicolumn{3}{|l|}{ Dominant landscape element type } \\
\hline in the $1880 \mathrm{~s}$ & Oak forest and Grassland & Pine forest \\
\hline in the $1980 \mathrm{~s}$ & Oak forest & Oak forest \\
\hline $\begin{array}{l}\text { Number of species of } \\
\text { element of natural forest }\end{array}$ & small & large \\
\hline
\end{tabular}

\section{DISCUSSION}

After the 1960s, these areas were abandoned due to the change away from traditional use. Most of the landscape changes were directly or indirectly induced by people. These changes and profound causing new changes in the landscape. In the urban fringes of Japan it has been shown that urbanization influences the boundaries of landscape elements (Fujihara et al. 2005). In the present study area, a management and restoration plan for the cultural landscape is being produced for the long-term conservation of the land, based on agricultural practices that were formerly common.

Ancient semi-natural woods are of highest importantance for nature conservation, because the component species of natural vegetation survive in these woodlands as a seed source. The woods and species within them have survived under traditional management, particularly coppicing. Fujihara (2001) documented that adjacent community affected landscape change. Presence of semi-natural woods is important for nature conservation. Fujihara \& Kikuchi (2005) revealed the regional differences in landscape structure at watershed scale. These changes in landscape structure were thought to be related to social and natural circumstances. Fujihara and Shirai (2001) documented landscape change in five different topographical areas and these changes were affected by farm system in the Boso Peninsula. In the present study, the differences in landscape structure and its change in the relatively fine scale level were clarified. Table 6 shows conceptual landscape structures at the two study sites. Most of areas at Fukumasu (site-a) were covered by low hills and grassland was a dominant landscape element in the 1880s. Grassland was used for several traditional purposes such as fertilizer and material for the roof of houses on site-a, and shrubs of forests were used for fuel and litter for compost on both sites. In the 1880s the productivity of cultivated land on site-a was greater than on site-b. Plant materials for fertilization, which were obtained from forests and grassland, seem to have been greater on site-a than site-b. On site-a people could used the forest floor and grassland frequently, because the slope was gentle. The frequency and magnitude of the disturbances seems to have been greater on site-a than on site-b. In the 1980s these areas were abandoned due to the change away from traditional use. Some abandoned vegetation areas changed into late successional stages, others changed to artificial land use. The number of species composing natural evergreen broad-leaved forests was greater on site-b than on site-a. The species composition of forests on former forests on both sites reflected the intensity of human disturbance. It is considered that the species composition of modern forests reflects the intensity of historic disturbance. 


\section{CONCLUSION}

Around the 1880s, evergreen coniferous forest composed of Pinus densiflora and deciduous broad leaved forest composed of $Q$. serrata were dominant and many patches of grassland were found in the Boso Peninsula, central Japan. Before the 1960s grassland was used for several traditional purposes such as fertilizer and material for the roof of houses and shrubs were also used for fuel and litter for compost. After the 1960s, these areas were abandoned due to the change away from traditional use. Some ab andoned vegetations changed into late successional stages, others changed to artificial land use. The areas of forest vegetation in the 1980s increased from 1880s. The species composition of forests on former forested land reflected the intensity of disturbance by residential people.

\section{ACKNOWLEDGMENTS}

The authors thank Dr. Yutaka Shirai of Natural History Museum and Institute, Chiba for valuable discussion and comments to historical land use. This study was supported by the Academic Frontier Joint Research Promoting Center of Tokyo University of Information Sciences, which was funded by the Ministry of Education, Culture, Sports, Science and Technology.

\section{REFERENCES}

Antrop, M. (2005). Why landscapes of the past are important for the future. Landscape and Urban Planning, 70, 21-34.

Arizono, S. (1994). Environment of Japan as land use maps circa 1850 see it. Historical Geography 167: 16-30. (In Japanese with English summary)

Braun-Blanquet, J. (1964). Pflanzen Soziologie. 3. Aufl. Springer-Verlag, Wien.

Cousins, S.A.O. (2001). Analysis of land-cover transitions based on 17th and 18th century cadastral maps and aerial photographs. Landscape Ecology, 16, 41-54.

Fujihara, M. (2001). Changes in pine forests and their adjacent communities in the Boso Peninsula, central Japan. Hikobia 13: 373-378.

Fujihara, M., Hara, K. \& Short, K. (2005). Changes in landscape structure of "Yatsu" valleys: a typical Japanese urban fringe landscape. Landscape and Urban Planning, Vol 70/3-4: 261-270.

Fujihara, M., Kikuchi, T. (2005). Changes in the landscape structure of the Nagara River Basin, central Japan. Landscape and Urban Planning,. Vol 70/3-4: 271-281.

Fujihara, M., Shirai, Y. (2001). Comparison of landscape structure in the 1880s and the 1980s at five areas of the Boso Peninsula, central Japan. Natural History Research 6: 8396.

Helliwell, D.R. (1976). The effects of size and isolation on the conservation value wooded sites in Britain. J. of Biogeography, 3: 407-416.

Iida, S., Nakashizuka, T. (1995). Forest fragmentation and its effect on species diversity in sub-urban coppice forests in Japan. Forest Ecology and Management, 7: 197-210.

Japan Meteorological Agency (1995). The Normals for AMeDAS Station in Japan (1979- 
1990). Technical Data Series No.60. Japan Meteorological Agency, Tokyo. (In Japanese with English summary)

Kadmon, R., Pulliam, R. (1993). Island biogeography: effect of geographical isolation on species composition. Ecology, 74: 977-981.

Kienast, F. (1993). Analysis of historic landscape patterns with a geographical information system - a methodological outline. Landscape Ecology, 8, 103-118.

Mueller-Dombois, D., Ellenberg, H. (1974). Aims and Methods of Vegetation Ecology. John Wiley and Sons, New York.

Shirai, Y. (1992). Structure of farmland environment from the view point of history. In Institute for Environment and Technology of Agriculture (Ed.), Farmland and Biotope, pp.17-37. Yokendo, Tokyo. (In Japanese)

Wimberly, M.C., Ohmann, J.L. (2004). A multi-scale assessment of human and environmental constraints on forest land cover change on the Oregon (USA) coast range. Landscape Ecology, 19: 631-646. 